\title{
Flora of Seed Plants in Longquan Mountain, Wuhan
}

\author{
Huan Dai ${ }^{*}$, Rujie $\mathrm{Xu}^{1}$, Xinyang Zhang ${ }^{1}$, and Jing Cai ${ }^{1}$ \\ ${ }^{1}$ Wuhan Institute of Design and Sciences, Wuhan 430205, China
}

\begin{abstract}
In recent years, in order to provide theoretical and scientific basis for the protection and rational utilization of plant resources in Lon longquan mountain gquan Mountain, the seed plants in Longquan Mountain were taken as the research object, and the field investigation was carried out by using the method of line plus typical sample plot, so as to further study the characteristics of investigated area were further studied. The results show: There are 231 species of 191 genus in 90 families, including 5 families, 9 genus and 11 species of gymnosperms, and 82 species of 182 genus and 85 species of angiosperms. The 14 distribution types of seed plants belong to the statistics: North temperate distribution There are 72 genus, accounting for $37.7 \%$ of the total genus of the area, reflecting the obvious north temperate nature of the flora. In addition, there are many ancient taxa and Cretaceous and Tertiary relict plants. There are 163 genus of single genus and genus genus, accounting for $85.3 \%$ of the total genus of the region, indicating that the plant origin is relatively old, there are 7 genus in China, which indicates that the unique phenomenon exists, but it is not obvious.
\end{abstract}

\section{Preface}

Floristic geography takes flora as the research object, aiming to explore the origin, evolution, spatial and temporal distribution of flora species and their relationship with the changes of Earth's historical environment. The geographical composition of flora is the basis of vegetation restoration. The analysis of the geographical components of plant flora in a specific region can reflect the regional characteristics of biodiversity, which has an indispensable basic data value for protecting and improving the local ecological environment and formulating biodiversity planning. It plays an important role in clarifying the object and focus of urban biodiversity protection and promoting urban-rural integration in urban landscaping. Investigation and analysis of plant species in urban biodiversity conservation should be strengthened to provide basic technical support for formulating more scientific, targeted and operable urban biodiversity conservation planning[1].

\section{Resarch area and method}

\subsection{Overview of the research area}

Wuhan is a subtropical monsoon climate with abundant rainfall and sufficient sunshine. The annual average temperature is $15.8^{\circ} \mathrm{C}-17.5^{\circ} \mathrm{C}$, the annual precipitation is $1100 \mathrm{~mm}$, the annual frost-free period is $240 \mathrm{~d}$, and the total annual sunshine duration is $2000 \mathrm{~h}$ [2]. Longquan Mountain Scenic Area is located in Longquan Township, Jiangxia District, Wuhan City, Geographical coordinates $114^{\circ} 30^{\prime} 05.66^{\prime \prime} \sim 114^{\circ} 31^{\prime} 25.15^{\prime \prime}, \quad 30^{\circ} 25^{\prime} 03.00^{\prime \prime}$ $30^{\circ} 24^{\prime} 17.69^{\prime \prime}$, altitude $232.5 \mathrm{~m}$.

\subsection{Research content}

In this study, Longquan Mountain in Wuhan City as the research object, the use of line survey and sample survey methods to investigate the species of seed plants in the region, and record the species of plants. According to the "Flora of China", the characteristics of plants in the survey area were analyzed and their lists were determined. According to the "Vegetation in China", the life forms of plants were divided as the standard. According to the ecological principles, the seed plants in Longquan Mountain were divided and their floristic characteristics were analyzed.

\subsection{Investigation method}

In the early stage, the vegetation of Longquan Mountain was investigated to determine the survey line and select the typical community to set up the survey sample plot. At the same time, the environmental factors such as longitude, latitude, altitude, slope and aspect of the sample plot were recorded. According to the minimum performance area method, which determine the sample area. Each survey sample area was $30 \mathrm{~m} \times 20 \mathrm{~m}$, and 20 samples was investigated and recorded the species composition.

\footnotetext{
*Corresponding author: 191735729@qq.com
} 


\section{Results and analysis}

\subsection{Species composition analysis}

The statistics of seed plants in Longquan Mountain was shown in Table 1. There are 231 species of seed plants belonging to 191 genus and 90 families, including 11 species of gymnosperms belonging to 9 genus and 5 families, and 220 species of angiosperms belonging to 182 genus and 85 families. Among them, 200 species of dicotyledons belonging to 160 genus and 77 families, and 20 species of monocotyledons belonging to 22 genus and 8 families.

Table1. Statistics of Seed Plants in Longquan Mountain

\begin{tabular}{ccccc}
\hline \multirow{2}{*}{ Item } & gymnosperm & \multicolumn{3}{c}{ Angiosperm } \\
\cline { 3 - 4 } & & Dicotyledon & Nonocotyledon & \\
\hline Families & 5 & 77 & 8 & 90 \\
Genus & 9 & 160 & 22 & 191 \\
Species & 11 & 200 & 20 & 231 \\
\hline
\end{tabular}

\subsection{Lifestyle analysis}

The life form of plants is a kind of plant type reflected in the appearance of plants for long-term adaptation to comprehensive habitat conditions, which is a manifestation of long-term adaptation of plants to a certain living environment[3]. According to the standard, the seed plants in Longquan Mountain were divided into arbors, shrubs, sub-shrubs, vines, annual and biennial herbs and perennial herbs according to ecological principles[4].

There are 59 perennial herbaceous plants and 29 annual or biennial herbaceous plants, accounting for $25.5 \%$ and $12.6 \%$ of the total species, respectively, accounting for $38.1 \%$. Woody plants include 63 species of trees, 64 species of shrubs and 1 species of subshrubs, accounting for $27.3 \%, 27.7 \%$ and $0.4 \%$ of the total species, respectively, accounting for $55.4 \%$. There are 15 species of vines, accounting for $6.5 \%$ of the total.

This data roughly reflects the diversity of life forms of seed plants in Longquan Mountain, in which woody plants are dominant.

\subsection{Divisional analysis of the Section}

\subsubsection{Composition analysis of the Section}

The composition of families, genus and species of seed plants in Longquan Mountain is shown in Table 2. There are 2 families with more than 15 species, 2 families with 10-14 larger species, and 3 families with 6-9 smaller species, accounting for $2.2 \%, 2.2 \%$ and $3.3 \%$ of the total families in Longquan Mountain, respectively. There were 19 small families with 3-5 species, and 64 families with 1-2 relatively single species, accounting for $21.1 \%$ and $71.1 \%$ of the total families in Longquan Mountain, respectively.
Table2. Families, genus and species composition of seed plants in Longquan Mountain

\begin{tabular}{|c|c|c|}
\hline $\begin{array}{c}\text { Serial } \\
\text { number }\end{array}$ & $\begin{array}{c}\text { Numbers of } \\
\text { species }\end{array}$ & Family \\
\hline 1 & $\begin{array}{l}\geq 15 \text { species } \\
(4 \text { families })\end{array}$ & Rosaceae, Leguminosae. \\
\hline 2 & $\begin{array}{c}10 \sim 14 \text { species } \\
\text { ( } 2 \text { families })\end{array}$ & Compositae, Gramineae. \\
\hline 3 & $\begin{array}{l}6 \sim 9 \text { species } \\
\text { ( } 3 \text { families })\end{array}$ & $\begin{array}{l}\text { Caryophyllaceae, } \\
\text { Polygonaceae and } \\
\text { Fagaceae. }\end{array}$ \\
\hline 4 & $\begin{array}{l}3 \sim 5 \text { species } \\
\text { ( } 19 \text { families })\end{array}$ & $\begin{array}{l}\text { Rutaceae, Lonicerae, } \\
\text { Pineaceae,Ranunculaceae, } \\
\text { Camphoraceae, Luteaceae, } \\
\text { Ulmaceae, Aristolochaceae, } \\
\text { Lilyaceae,etc. }\end{array}$ \\
\hline 5 & $\begin{array}{l}1 \sim 2 \text { species } \\
\text { ( } 64 \text { families })\end{array}$ & $\begin{array}{l}\text { Moraceae, } \\
\text { Caryophyllaceae, } \\
\text { Verbenaceae, } \\
\text { Rhododendronaceae, } \\
\text { Lacqueraceae, Grapeaceae, } \\
\text { Zoysia, Ornithaceae, } \\
\text { Taxaceae, etc. }\end{array}$ \\
\hline
\end{tabular}

It is indicated that the minor section and the comparative single section play an important role in the survey area and are an important part of the composition of the survey area. There are 19 small families of $3 \sim 5$ species and 64 single families of 1 2 species in Longquan Mountain, accounting for $92.2 \%$ of the total families. The above characteristics reflect the diversity of floristic elements in the survey area.

\subsubsection{Statistical Analysis of the Advantage Section}

Among the 90 families of plant flora in the investigated area, there are 7 families with more than 6 species, constituting the dominant families, accounting for only $7.8 \%$ of the total families in the region, but the number of genus and species is 55 and 77 , accounting for $28.8 \%$ and $33.3 \%$ of the total genus and species, respectively. It is indicated that the seed plant composition of Longquan Mountain is concentrated in these dominant families, which constitute the main species composition of the investigated flora.

\subsubsection{Floristic analysis of areal types of family}

The 90 families of seed plants in Longquan Mountain are divided into 13 types, 42 families in the north temperate zone and 21 families in the pantropical zone, accounting for $46.7 \%$ and $23.3 \%$ of the families in the survey area, respectively. World distribution of 15 families, tropical Asia distribution of 13 families, East Asia and North America intermittent distribution of 9 families, East Asia distribution of 8 families, tropical Asia and tropical Oceania distribution of 5 families, accounting for $16.7 \%$, $14.4 \%, 10.0 \%, 8.9 \%, 5.6 \%$ of the number of families in this area. The tropical distribution in the old world, tropical Asia to tropical Africa, the Mediterranean region and Central Asia to West Asia are 3 families, accounting 
for $3.3 \%$ of the total number of families in the region, there are 7 families endemic to China, accounting for $7.8 \%$.

Table3. Distribution types of seed plant families in Longquan Mountain

\begin{tabular}{|c|c|c|c|}
\hline $\begin{array}{l}\text { Serial } \\
\text { number }\end{array}$ & $\begin{array}{c}\text { Distribution areas and } \\
\text { subtypes }\end{array}$ & $\begin{array}{l}\text { Number } \\
\text { of } \\
\text { District } \\
\text { Sections } \\
\end{array}$ & $\begin{array}{c}\text { Proportion } \\
\text { of sections } \\
\text { in the region } \\
\quad / \% \\
\end{array}$ \\
\hline 1 & World distribution & 15 & 16.7 \\
\hline 2 & $\begin{array}{l}\text { Pantropical } \\
\text { distribution }\end{array}$ & 21 & 23.3 \\
\hline 3 & $\begin{array}{l}\text { Tropical distribution } \\
\text { in the old world }\end{array}$ & 3 & 3.3 \\
\hline 4 & $\begin{array}{l}\text { Tropical Asia and } \\
\text { tropical Oceania } \\
\text { distribution }\end{array}$ & 5 & 5.6 \\
\hline 5 & $\begin{array}{l}\text { Distribution of } \\
\text { tropical Asia to } \\
\text { tropical Africa }\end{array}$ & 3 & 3.3 \\
\hline 6 & $\begin{array}{l}\text { Tropical Asia } \\
\text { distribution }\end{array}$ & 13 & 14.4 \\
\hline 7 & $\begin{array}{l}\text { North temperate } \\
\text { distribution }\end{array}$ & 42 & 46.7 \\
\hline 8 & $\begin{array}{c}\text { Intermittent } \\
\text { distribution of south } \\
\text { and north temperate } \\
\text { zones }\end{array}$ & 2 & 2.2 \\
\hline 9 & $\begin{array}{c}\text { Intermittent } \\
\text { distribution of East } \\
\text { Asia and North } \\
\text { America }\end{array}$ & 9 & 10.0 \\
\hline 10 & $\begin{array}{l}\text { Old world temperate } \\
\text { distribution }\end{array}$ & 4 & 4.4 \\
\hline 11 & $\begin{array}{c}\text { Distribution of } \\
\text { Mediterranean, } \\
\text { Central and Western } \\
\text { Asia }\end{array}$ & 3 & 3.3 \\
\hline 12 & E. asia flora & 8 & 8.9 \\
\hline 13 & $\begin{array}{l}\text { China - specific } \\
\text { distribution }\end{array}$ & 7 & 7.8 \\
\hline Total & & 77 & 100 \\
\hline
\end{tabular}

Table 3 shows that the largest number of families in the north temperate zone is 42 families, accounting for $46.7 \%$, which fully shows the nature of the north temperate flora of Longquan Mountain. Pantropical distribution of 21 families, considerable proportion of $23.3 \%$. There are also Chinese endemic families in the survey area, such as Sapinaceae, Ginkgoaceae, Leguminosae and Rutaceae, Eucommiaceae, indicating that the endemic phenomenon in the survey area is not obvious from the perspective of families.

\subsubsection{Analysis of genus flora}

The flora of seed plants in Longquan Mountain contains 4 or more genus, including Rosa, Lespedeza, Pinus and Quercus. There are 3 species of medium genus, such as Rubus, Polygonum, Photinia. There are 21 genus of small genus including 2 species, such as Pentaphyllum, Compositae, Chrysanthemum, etc. There are 163 genus including one species, such as Rancidum, Lycopersicon and Torilis, the grouping list is shown in Table4.
Table4. List of Genus of Seed Plants in Longquan Mountain

\begin{tabular}{cccccc}
\hline $\begin{array}{c}\text { Serial } \\
\text { number }\end{array}$ & $\begin{array}{c}\text { Number } \\
\text { of } \\
\text { familes }\end{array}$ & $\begin{array}{c}\text { Number } \\
\text { of genus }\end{array}$ & $\begin{array}{c}\text { Proportion } \\
\text { of total } \\
\text { species } / \%\end{array}$ & $\begin{array}{c}\text { Number } \\
\text { of } \\
\text { species }\end{array}$ & $\begin{array}{c}\text { Proportion } \\
\text { of total } \\
\text { species } / \%\end{array}$ \\
\hline 1 & $\geq 4$ & 4 & 2.1 & 18 & 7.8 \\
2 & 3 & 3 & 1.6 & 6 & 2.6 \\
3 & 2 & 21 & 11.0 & 44 & 19.0 \\
4 & 1 & 163 & 85.3 & 163 & 70.6 \\
Total & & 191 & 100 & 231 & 100 \\
\hline
\end{tabular}

The 4 species and more than 4 species, accounting for $2.1 \%$ of the total number of genus, but the number of species accounted for $7.8 \%$ of the total number of species, indicating that these 4 genus are the dominant genus in the flora. Among the four dominant genus, Rosa, Pine and Quercus were distributed in the north temperate zone, and Lespedeza was distributed intermittently in East Asia and North America, indicating that the park had obvious north temperate nature. Analysis of the origin of the flora shows that: 1 species of gymnosperms belonging to 9 genus and 5 families in this area, including Pinus and Platycladus, are ancient groups in seed plants, the angiosperms of Magnoliaceae, Ranunculaceae. Berberaceae, Fagaceae, Ulmaceae, Mulaceae, Aceraceae and other plants all appeared in Cretaceous or Tertiary, and the monospecies and oligospecies in this area were 163 genus, accounting for $85.3 \%$ of the total genus. These species and structures reflect the relatively ancient origin of flora in the region.

The distribution type of genus can more specifically reflect the differentiation and geographical characteristics of the plant community in the process of evolution. The geographical distribution type of genus represents the geographical components of genus, which, to a certain extent, contains the historical development process of various floras contained in it, and is the basis and symbol the division of flora[6]. According to Professor Wu Zhengyi ' s classification of seed plants in China, 191 genus of seed plants in Longquan Mountain were divided into 14 distribution types. Table 5 shows that the distribution genus of the North Temperate Zone accounted for the largest proportion, 72 genus, accounting for $37.7 \%$ of the total genus in this area. the second is pantropical distribution, with 34 genus, accounting for $17.8 \%$ of the total genus in the region. Again is the world distribution, there are 21 genus, accounting for $11.0 \%$ of the total number of genus. There are 79 genus of seed plants in the temperate zone, accounting for $41.4 \%$ of the total genus.

There are 61 genus of tropical nature, accounting for $31.9 \%$ of the total genus in this area. It shows that the flora of seed plants in Longquan Mountain shows obvious temperate characteristics. The floristic relationship between the genus of seed plants in Longquan Mountain and the genus of plants in other parts of the world : In the nature of the temperate zone, the distribution of the northern temperate zone is $37.7 \%$, the most closely related is the intermittent distribution of East Asia and North America 5.2 \%, the distribution of East Asia 5.2 \%, followed by the distribution of the old world temperate $2.6 \%$, and the relationship with other distribution types is 
poor. In the tropical nature, it is closely related to $17.8 \%$ of pan-tropical distribution, followed by $7.3 \%$ of tropical Asia distribution, and other distribution types are relatively poor. Analysis of the origin and endemic components of the flora: There are 7 genus and 7 species endemic to China in the flora of Longquan Mountain, which are Koelreuteria, Toona, Ginkgo, Horseshoe, Honeybean, Citrus, Eucommia, accounting for $3.7 \%$ of the total number of genus in this area. The Chinese endemic genus in Longquan Mountain account for $22.6 \%$ of the 31 Chinese endemic genus in Central China, and $2.7 \%$ of the 260 Chinese endemic genus, indicating that the endemic phenomena in this area occupy a certain proportion but not obvious.

Table5. The distribution type and species number of seed plants in Longquan Mountain

\begin{tabular}{|c|c|c|c|}
\hline $\begin{array}{c}\text { Serial } \\
\text { number }\end{array}$ & Distribution type & $\begin{array}{l}\text { Numbers } \\
\text { of genus }\end{array}$ & $\begin{array}{c}\text { Proportion } \\
\text { of total } \\
\text { genus } / \% \\
\end{array}$ \\
\hline 1 & World distribution & 21 & 11.0 \\
\hline 2 & $\begin{array}{l}\text { Pantropical } \\
\text { distribution }\end{array}$ & 34 & 17.8 \\
\hline 3 & $\begin{array}{l}\text { Tropical distribution } \\
\text { in the old world }\end{array}$ & 3 & 1.6 \\
\hline 4 & $\begin{array}{l}\text { Tropical Asia and } \\
\text { tropical Oceania } \\
\text { distribution }\end{array}$ & 2 & 1.0 \\
\hline 5 & $\begin{array}{l}\text { Distribution of } \\
\text { tropical Asia to } \\
\text { tropical Africa }\end{array}$ & 5 & 2.6 \\
\hline 6 & $\begin{array}{l}\text { Tropical Asia } \\
\text { distribution }\end{array}$ & 3 & 1.6 \\
\hline 7 & tropical asia & 14 & 7.3 \\
\hline 8 & $\begin{array}{l}\text { North temperate } \\
\text { distribution }\end{array}$ & 72 & 37.7 \\
\hline 9 & $\begin{array}{c}\text { Intermittent } \\
\text { distribution of south } \\
\text { and north temperate } \\
\text { zones }\end{array}$ & 2 & 1.0 \\
\hline 10 & $\begin{array}{l}\text { Intermittent } \\
\text { distribution of East } \\
\text { Asia and North } \\
\text { America }\end{array}$ & 10 & 5.2 \\
\hline 11 & $\begin{array}{l}\text { Old world temperate } \\
\text { distribution }\end{array}$ & 5 & 2.6 \\
\hline 12 & $\begin{array}{c}\text { Distribution of } \\
\text { Mediterranean, } \\
\text { Central and Western } \\
\text { Asia }\end{array}$ & 3 & 1.6 \\
\hline 13 & E. asia flora & 10 & 5.2 \\
\hline 14 & $\begin{array}{l}\text { China - specific } \\
\text { distribution }\end{array}$ & 7 & 3.7 \\
\hline Total & & 0 & 100 \\
\hline
\end{tabular}

\section{Conclusions and discussion}

Geographical composition analysis of genus and species in the study of flora, the distribution type of genus can reflect the differentiation and geographical characteristics of the flora in the evolution process. In terms of floristic composition, the life forms of seed plants are diverse, woody plants are developed and rich in species, which have obvious characteristics of northern temperate vegetation. In terms of geographical components, the North Temperate Zone is the most widely distributed, with 72 genus, accounting for $37.7 \%$ of the total number of genus in the region, and the most closely related are the intermittent distribution and East Asian distribution of East Asia and North America, which account for 5.2\% of the total number of genus in the region, reflecting the obvious nature of the North Temperate Zone. In terms of the origin characteristics and endemic phenomena, seed plants are relatively old in origin, and there are many ancient groups and relic plants of Cretaceous and Tertiary. For example, some species of gymnosperms, angiosperms, such as Magnoliaceae, Ranunculaceae, Berberaceae, Fagaceae and Ulmaceae in this area, and the proportion of monotypic and oligotypic genus in this area is large. There are 7 species of endemic genus in China, and endemic phenomena exist, but not obvious.

Plants with poor adaptability and high ornamental value should be introduced gradually, which can be first introduced to the nursery or botanical garden for domestication, and then widely applied. For some precious and rare ornamental plants, they should be preserved and expanded by modern technology, and then developed and utilized to avoid species extinction[6-7]. All in all, wild ornamental plants should be rationally utilized and developed to serve urban landscaping so as to maximize their value.

\section{Acknowledgments}

This research was financially supported by the Scientific Resarch Project of Wuhan Institute of Design and Sciences (K201915), the Project of Excellent Course (201308), the Project of Teaching Research(2020JY104 and 2019JY111), and the Teaching Resarch Project of Hubei Provincal Universities (2018496 and 2017505).

\section{References}

1. $P$. Wei, $Y$. Guo, J. Bai, $Y$. Zhang, J. Guo, JSAS, 46, 4, 606-611(2018)

2. B. Zhang, IMF, 12, 26-27(2014)

3. $X$. Liu, $Y$. Zhang, $Y$. Wang, $H$. Yang, $Z$. Ma, JGAU, 53, 5, 118-126(2018)

4. G. Li, L. Gao, Y. Zhang, N. Yang, FES, 33, 4, 387394(2018)

5. Z. Wu, H. Sun, Z. Zhou, D. Li, H. Peng, SP, (2011)

6. D. Tang, $Y$. Wu, $W$. Liu, D. Li, G. Yang, $Q$. Chen, $T$. Zhang, APS, 36, 05, 658-666(2018)

7. $B$. Bai, $X$. Wang, $Y$. Huang, $M$. Chen, JANU(NS)43, 05, 459-466(2020) 